\title{
Analysis, Calculation and Reduction of Shaft Voltage in Induction Generators
}

\author{
Jafar Adabi, Firuz Zare \\ School of Electrical Engineering, Queensland University of Technology, GPO Box 2434, Brisbane, QLD, 4001, Australia \\ Email: adabi.jafar@student.qut.edu.au , f.zare@qut.edu.au
}

\begin{abstract}
This paper presents analysis of shaft voltage in different configurations of a Doubly Fed Induction Generator (DFIG) and an Induction Generator (IG) with a back-to-back inverter in wind turbine applications. Detailed high frequency model of the proposed systems have been developed based on existing capacitive couplings in IG \& DFIG structures and common mode voltage sources. In this research work, several arrangements of DFIG based wind energy conversion systems are investigated on shaft voltage calculation and its mitigation techniques. Placements of an LC line filter in different locations and its effects on shaft voltage elimination are studied with mathematical analysis and simulations.
\end{abstract}

\section{Key words}

Induction generators, DFIG, back- to - back inverter, shaft voltage, common mode model, filter

\section{Introduction}

Recently, DFIGs have played a significant role in converting wind energy to electricity [1]. The main types of wind turbines are presented in [2-3] which are: (a) a fixed speed wind turbine with an asynchronous squirrel cage IG directly connected to a grid via a transformer (b) a variable speed wind turbine with a DFIG and blade pitch control (c) a variable speed wind turbine using a permanent magnet synchronous generator that is connected to the grid through a full-scale frequency converter. To achieve a variable speed constant frequency system, an IG is considered attractive due to its flexible rotor speed characteristics with respect to the constant stator frequency. One solution to expand the speed range and reduce the slip power losses is to doubly excite the stator and rotor windings [4]. In a DFIG, the stator is directly connected to the grid, while the wound rotor is fed from a back-to-back converter via slip rings to allow the DIFG to operate at a variety of speeds in order to accommodate changing wind speeds. The slip power can flow in both directions to the rotor from the supply and from the supply to the rotor and hence the speed of the machine can be controlled from either the rotor- or stator-side converter in both super and sub-synchronous speed ranges [5].

The main issues regarding the operation of power converters used in IG and DFIG structures are high dv/dt (fast switching transients) and common mode voltage generated by a pulse width modulated voltage which can lead to a shaft voltage and resultant bearing currents, grounding current escaping to earth through stray capacitors inside a motor, conducted and radiated noises [6-7]. Shaft voltage is influenced by various factors such as: capacitive couplings between different parts of the machine structure, the configuration of the main supply, voltage transient on the machine terminals, and switching states in PWM pattern. Common mode voltage is a very important factor in the high frequency modelling of a generator and is seen as a potential origin of shaft voltage in high switching frequencies [7]. Its reduction techniques [8] play a main role in attenuation of high frequency related problems of the AC motor drives.

Fig.1 shows the configuration of a three phase inverter. $\mathrm{V}_{\text {no }}$, the voltage between neutral point and the ground (common mode voltage) is:

$\mathrm{V}_{\mathrm{no}}(\mathrm{t})=\frac{\mathrm{V}_{\mathrm{ao}}(\mathrm{t})+\mathrm{V}_{\mathrm{bo}}(\mathrm{t})+\mathrm{V}_{\mathrm{co}}(\mathrm{t})}{3}=\mathrm{V}_{\mathrm{com}}$

Where $\left(\mathrm{V}_{\mathrm{ao}}, \mathrm{V}_{\mathrm{bo}}, \mathrm{V}_{\mathrm{co}}\right)$ are the leg voltages. Using the appropriate switching pattern, the common mode voltage level can be controlled [9]. Switching states of the proposed converter and the common mode voltage are shown in Table. I.

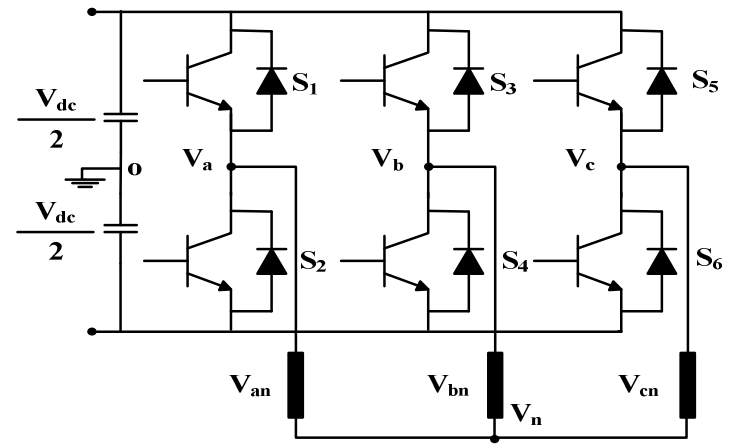

Fig.1. A three phase converter

Table I. Switching states and common mode voltage of a three phase inverter

\begin{tabular}{|c|c|}
\hline Switching vectors $\left(\mathrm{S}_{1}, \mathrm{~S}_{3}, \mathrm{~S}_{5}\right)$ & $\mathrm{V}_{\mathrm{com}}$ \\
\hline $\mathrm{V}_{1}(100), \mathrm{V}_{3}(010), \mathrm{V}_{5}(001)$ & $-\frac{\mathrm{V}_{\mathrm{dc}}}{6}$ \\
\hline $\mathrm{V}_{2}(110), \mathrm{V}_{4}(011), \mathrm{V}_{6}(101)$ & $\frac{\mathrm{V}_{\mathrm{dc}}}{6}$ \\
\hline $\mathrm{V}_{7}(111)$ & $\frac{\mathrm{V}_{\mathrm{dc}}}{2}$ \\
\hline $\mathrm{V}_{0}(000)$ & $-\frac{\mathrm{V}_{\mathrm{dc}}}{2}$ \\
\hline
\end{tabular}

Fig. 2 shows the arrangement of a back-to-back inverter. In this structure, the common mode voltages of the both sides are given as:

$$
\mathrm{V}_{\text {com }, 1}=\frac{\mathrm{V}_{\mathrm{a}}+\mathrm{V}_{\mathrm{b}}+\mathrm{V}_{\mathrm{c}}}{3}, \mathrm{~V}_{\text {com }, 2}=\frac{\mathrm{V}_{\mathrm{x}}+\mathrm{V}_{\mathrm{y}}+\mathrm{V}_{\mathrm{z}}}{3}
$$

Where $\mathrm{V}_{\mathrm{a}}, \mathrm{V}_{\mathrm{b}}, \mathrm{V}_{\mathrm{c}} \& \mathrm{~V}_{\mathrm{x}}, \mathrm{V}_{\mathrm{y}}, \mathrm{V}_{\mathrm{z}}$ are the leg voltages for converter1 and converter 2 respectively. The capacitive coupling between different parts of generator structure is another issue in high frequency analysis [9]. The 
common mode voltage and parasitic capacitances create a high frequency equivalent circuit for Induction generators to generate shaft voltage. Recently, some techniques are presented to mitigate shaft voltage and bearing currents in DFIGs. An approach is used in [10] to constrain the inverter PWM strategy to reduce the overall common mode voltages across the rectifier/inverter system, and thus significantly reduce bearing discharge currents. A common mode model of DFIGs is mentioned in [11] to calculate bearing current.

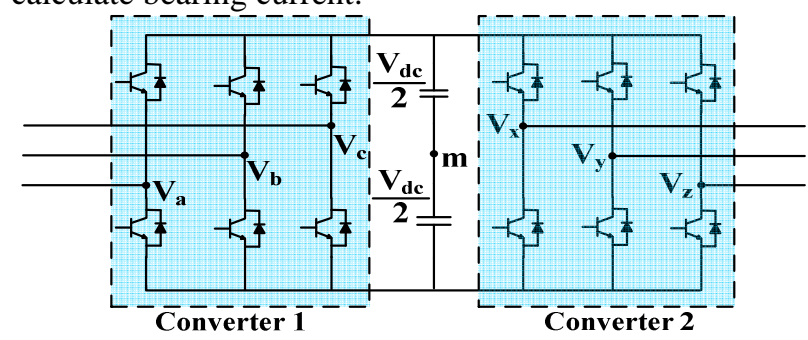

Fig.2. A back-to-back inverter

This paper focuses on the shaft voltage analysis (topologies, high frequency model, calculation, mitigation techniques) of IGs and DFIGs in wind turbine applications. Different LC filter placements will be analysed to eliminate the shaft voltage by means of accurate high frequency model of the grid-connected wind generators.

\section{Shaft voltage generated by converters in a stator-fed induction generator}

Fig.3.a shows the structures of an IG where the parasitic capacitive couplings exist between: the stator winding and rotor $\left(\mathrm{C}_{\mathrm{sr}}\right)$, the stator winding and stator frame $\left(\mathrm{C}_{\mathrm{sf}}\right)$, between the rotor and stator frames $\left(\mathrm{C}_{\mathrm{rf}}\right)$, and ball bearing and outer and inner races $\left(\mathrm{C}_{\mathrm{b} 1}, \mathrm{C}_{\mathrm{b} 2}\right)$. Fig.3.b shows an induction generator wind turbine structure in which a power converter is connected between the generator and the grid. In this case, the voltage stress is from the stator winding. Common mode voltage creates the shaft voltage through electrostatic couplings between the rotor and the stator windings and between the rotor and the frame. A simple high frequency model of a motor drive is shown in Fig.3.c and shaft voltage can be calculated as:

$\mathrm{V}_{\text {shaft }}=\frac{\mathrm{C}_{\mathrm{sr}}}{\mathrm{C}_{\mathrm{b}}+\mathrm{C}_{\mathrm{rf}}+\mathrm{C}_{\mathrm{sr}}} \times \mathrm{V}_{\text {com }}$

Fig.3.d shows a view of a stator slot, a rotor and winding where $g_{1}$ is the air gap between rotor and stator, $g_{2}$ is the gap between winding and stator and $g_{\text {in }}$ is the thickness of the winding insulation. $d$ is the length of slot tooth and $\rho$ is the height of the stator slot. $\mathrm{W}$ and $\mathrm{W}^{\prime}$ are the width of winding at the top and bottom respectively. $h_{W}$ is the length of the stator winding at both the right and the left side of winding. Different capacitive couplings in a single stator slot can be approximately calculated as:

$$
\left\{\begin{array}{l}
\mathrm{C}_{\mathrm{rf}} \approx \frac{\varepsilon_{0}\left(\frac{2 \pi \mathrm{r}}{\mathrm{n}}-\mathrm{d}\right) \times \mathrm{L}_{\mathrm{r}}}{\mathrm{g}_{1}} \\
\mathrm{C}_{\mathrm{sf}} \approx\left(\frac{\varepsilon_{0} \varepsilon_{\mathrm{r}}\left(\mathrm{W}^{\prime}+2 \times \mathrm{h}_{\mathrm{W}}\right)}{\mathrm{g}_{\mathrm{in}}}+\frac{\varepsilon_{0} \varepsilon_{\mathrm{r} 1} \varepsilon_{\mathrm{r} 2}(\mathrm{~W}-\mathrm{d})}{\mathrm{g}_{2} \varepsilon_{\mathrm{r} 1}+\mathrm{g}_{\mathrm{in}} \varepsilon_{\mathrm{r} 2}}\right) \times \mathrm{L}_{\mathrm{r}} \\
\mathrm{C}_{\mathrm{sr}} \approx \varepsilon_{0} \frac{\mathrm{d}-\rho}{\rho+\mathrm{g}_{1}+\mathrm{g}_{2}}
\end{array}\right.
$$

Where $r$ is the rotor radius and $g_{1}$ is the air gap, $L_{r}$ is the rotor length. $\varepsilon_{0}$ is the permittivity of free space and $\varepsilon_{\mathrm{r} 1}, \varepsilon_{\mathrm{r} 2}$ are the permittivity of the insulation and the slot wedge materials. By substituting of Eq.4 in Eq.3, the ratio between shaft voltage and common mode voltage can be written as:

$$
\frac{\mathrm{V}_{\text {shaft }}}{\mathrm{V}_{\text {com }}} \approx \frac{\mathrm{g}_{1}(\mathrm{~d}-\rho)}{\mathrm{g}_{1}(1+\mathrm{x})(\mathrm{d}-\rho)+\left(\rho+\mathrm{g}_{1}+\mathrm{g}_{2}\right)\left(\frac{2 \pi \mathrm{r}}{\mathrm{n}}-\mathrm{d}\right)}, \mathrm{d}>\rho
$$

Where $\mathrm{x}$ is the ratio between bearing capacitance and $\mathrm{C}_{\mathrm{sr}}$. As shown in this equation, the effective parameters on shaft voltage are $d, \rho, g_{1}$ and $g_{2}$. It is clear that $g_{1}$ can not be changed for a large range of variation and can not be an effective parameter in shaft voltage reduction.

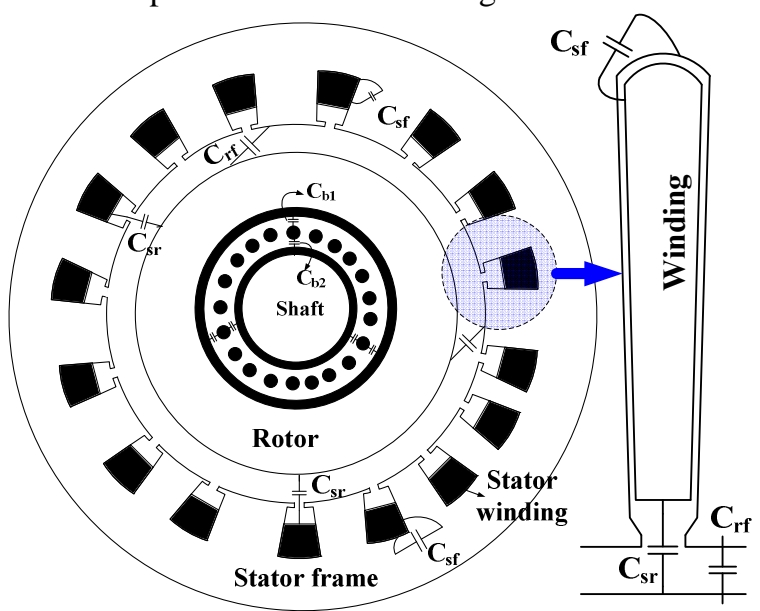

(a)

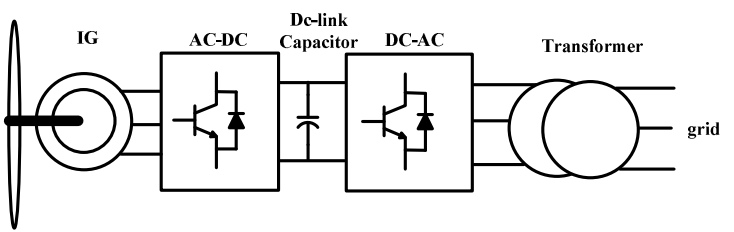

(b)

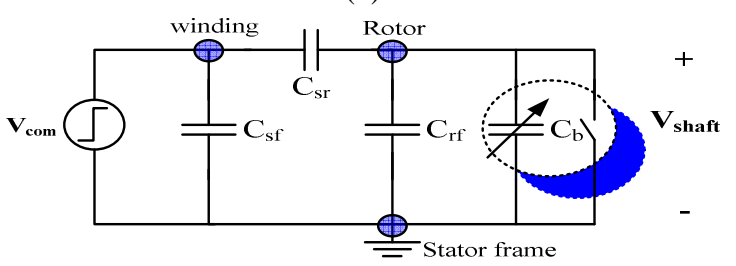

(c)

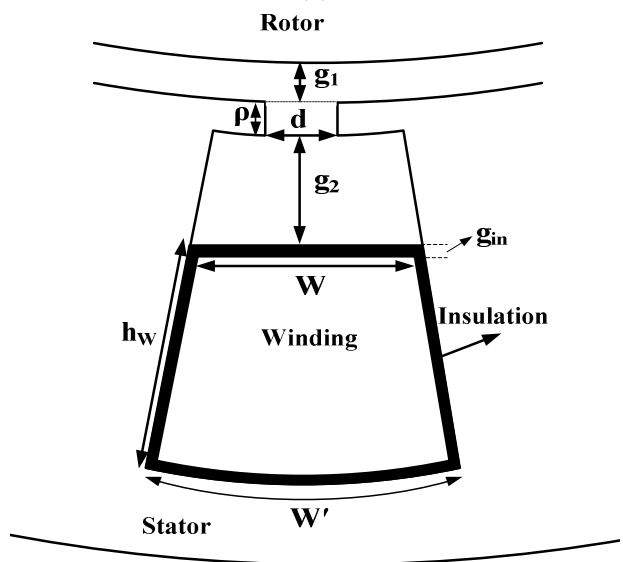

(d)

Fig.3. (a) Structure of a stator fed induction generator with different parasitic capacitive couplings (b) with an AC-DC$\mathrm{AC}$ converter and its (c) Its high frequency model (d) a stator slot and different design parameters 
Fig.4 shows the variation of $\mathrm{V}_{\text {shaft }} / \mathrm{V}_{\text {com }}$ versus variation of $d$ and $g_{2}$ stator slot height of $\rho=5 \mathrm{~mm}$. This graph shows the effect of two main design parameters on shaft.

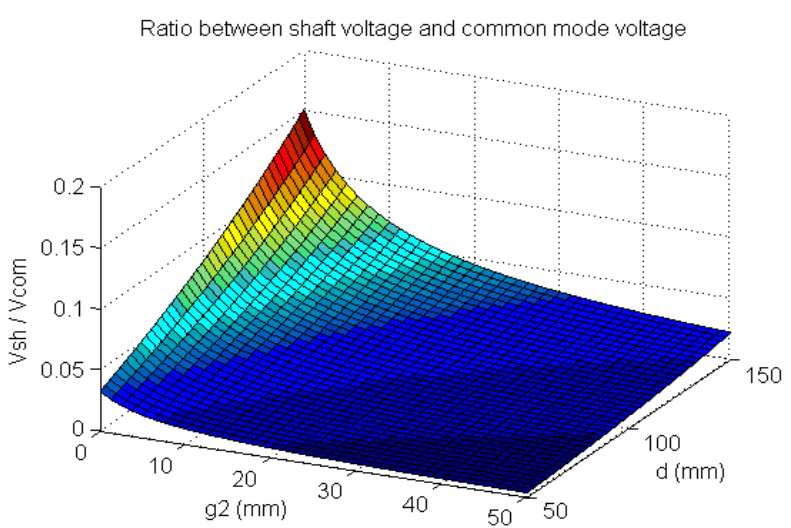

Fig.4. $\mathrm{V}_{\text {sh }} / \mathrm{V}_{\text {com }}$ versus $\mathrm{d}$ and $\mathrm{g}_{2}(\rho=5 \mathrm{~mm}, \mathrm{x}=1)$

According to simulation results in different parameters: - $\mathrm{C}_{\mathrm{sr}}$ is an important capacitance in case of shaft voltage generation because it can be changed by variation of the design parameters while other capacitances have not such a freedom to change.

- An increment of stator slot tooth increases the shaft voltage while increasing the gap between the slot tooth and winding decreasing the shaft voltage (see Fig.4). This information can be taken into account in the design procedure of the motor structure and the motor designer can choose design parameters which are a trade off between shaft voltage issue and other electromechanical considerations.

\section{Shaft voltage generated by converters in a doubly-fed induction generator}

Fig. 5 shows the structures of a DFIG where the parasitic capacitive couplings exist between: the stator winding and rotor $\left(\mathrm{C}_{\mathrm{sr}}\right)$, the stator winding and stator frame $\left(\mathrm{C}_{\mathrm{sf}}\right)$, between the rotor and stator frames $\left(\mathrm{C}_{\mathrm{rf}}\right)$, stator winding and rotor winding $\left(\mathrm{C}_{\mathrm{ws}}\right)$, the rotor winding and rotor $\left(\mathrm{C}_{\mathrm{wr}}\right)$, rotor winding and stator frame $\left(\mathrm{C}_{\mathrm{wf}}\right)$ and ball bearing and outer and inner races $\left(\mathrm{C}_{\mathrm{b} 1}, \mathrm{C}_{\mathrm{b} 2}\right)$.

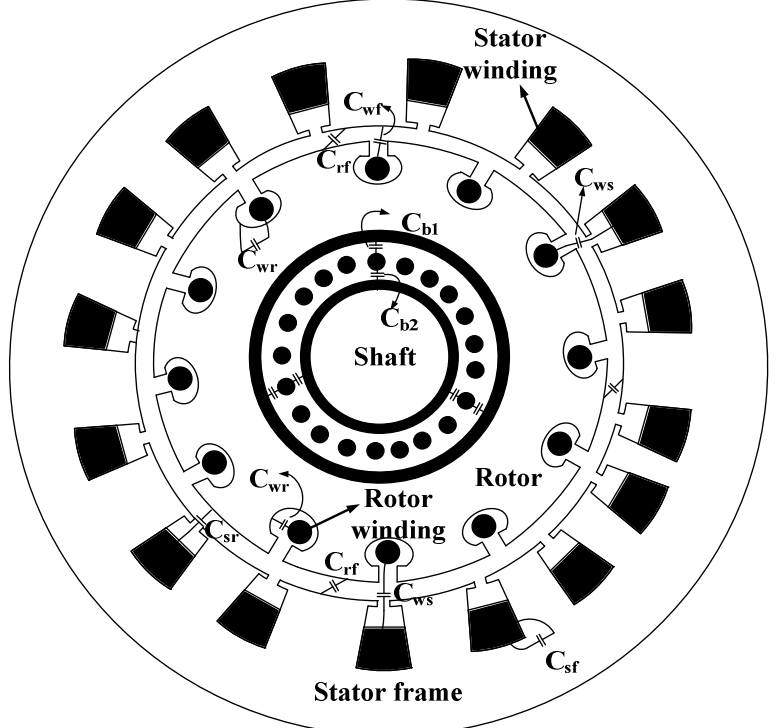

Fig.5. A view of a doubly fed induction generator with different parasitic capacitive couplings
In this section, different topologies of a DFIG with a four-quadrant AC-DC-AC converter connected and different placements of LC filters in both rotor and stator sides, and a line filter has been investigated (see Fig.6). In general, only the line side current is required to be sinusoidal to satisfy IEEE standards [10]. The typical values of $\mathrm{C}_{\mathrm{wr}}=5 \mathrm{nF}, \mathrm{C}_{\mathrm{rf}}=0.6 \mathrm{nF}, \mathrm{C}_{\mathrm{sr}}=0.3 \mathrm{nF}, \mathrm{C}_{\mathrm{b}}=0.1 \mathrm{nF}$ are employed for capacitive couplings in the following.

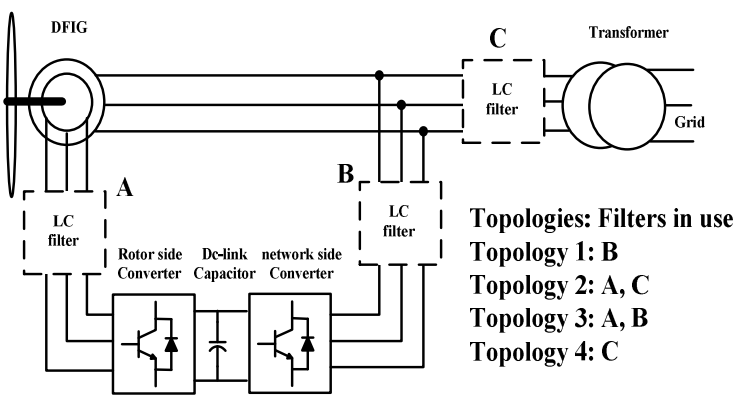

Fig.6. different placements of L-C filters in wind turbine applications in a DFIG with a back to back converter

Topology1: As shown in Fig.6, the network side converter is connected to the grid through a line LC filter which is used to damp the higher order harmonics generated by the switching of semiconductors switches. This filter is used as a tool to provide reactive power in order to enable power factor correction on the network within a desired range [11]. The LC filter which connects the net-side converter to the grid reduces the harmonics and the voltage waveform on the stator side has not a PWM waveform anymore. Therefore there is no common mode voltage source in this configuration. An arrangement of capacitive couplings of a DFIG with an LC filter on the network side converter is shown in Fig.7.

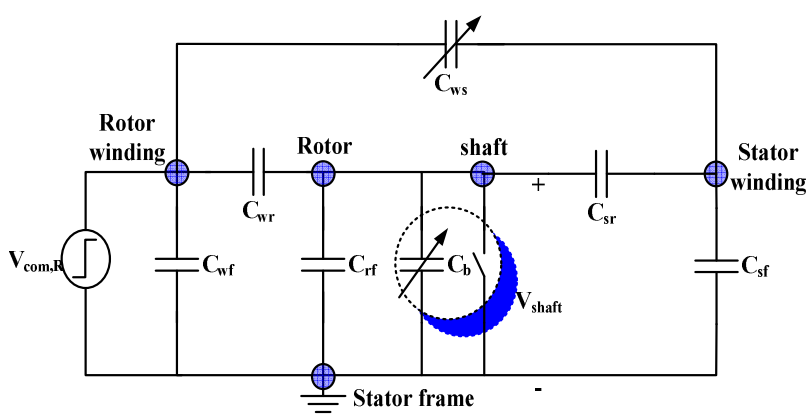

Fig.7. High frequency model a DFIG with Topology1

In this case, the only common mode voltage source is from the rotor winding and this voltage stress creates shaft voltage which can be easily calculated by a KCL analysis. Considering $\mathrm{C}_{\mathrm{sr}}$ as a small value and $\mathrm{C}_{\mathrm{sr}}<<\mathrm{C}_{\mathrm{wr}}$ :

$\left\{\begin{array}{l}\mathrm{V}_{\text {shaft }}=\frac{\mathrm{C}_{\mathrm{wr}} \times\left(\mathrm{C}_{\mathrm{sf}}+\mathrm{C}_{\mathrm{sr}}+\mathrm{C}_{\mathrm{ws}}\right)+\mathrm{C}_{\mathrm{ws}} \times \mathrm{C}_{\mathrm{sr}}}{\left(\mathrm{C}_{\mathrm{wr}}+\mathrm{C}_{\mathrm{rf}}+\mathrm{C}_{\mathrm{b}}+\mathrm{C}_{\mathrm{sr}}\right) \times\left(\mathrm{C}_{\mathrm{sf}}+\mathrm{C}_{\mathrm{sr}}+\mathrm{C}_{\mathrm{ws}}\right)-\mathrm{C}_{\mathrm{sr}}{ }^{2}} \times \mathrm{V}_{\mathrm{com} \mathrm{R}} \\ \text { and } \\ \mathrm{C}_{\mathrm{sr}} \times \mathrm{C}_{\mathrm{ws}}<<\mathrm{C}_{\mathrm{wr}} \times\left(\mathrm{C}_{\mathrm{sf}}+\mathrm{C}_{\mathrm{sr}}+\mathrm{C}_{\mathrm{ws}}\right) \text { and } \mathrm{C}_{\mathrm{sr}}{ }^{2} \approx 0\end{array}\right.$

Thus, shaft voltage can be simplified as follows:

$\mathrm{V}_{\text {shaft }} \approx \frac{\mathrm{C}_{\mathrm{wr}}}{\left(\mathrm{C}_{\mathrm{wr}}+\mathrm{C}_{\mathrm{rf}}+\mathrm{C}_{\mathrm{b}}+\mathrm{C}_{\mathrm{sr}}\right)} \times \mathrm{V}_{\text {com, } \mathrm{R}}$

$\mathrm{V}_{\text {com, } \mathrm{R}}$ is the rotor side common mode voltage. 

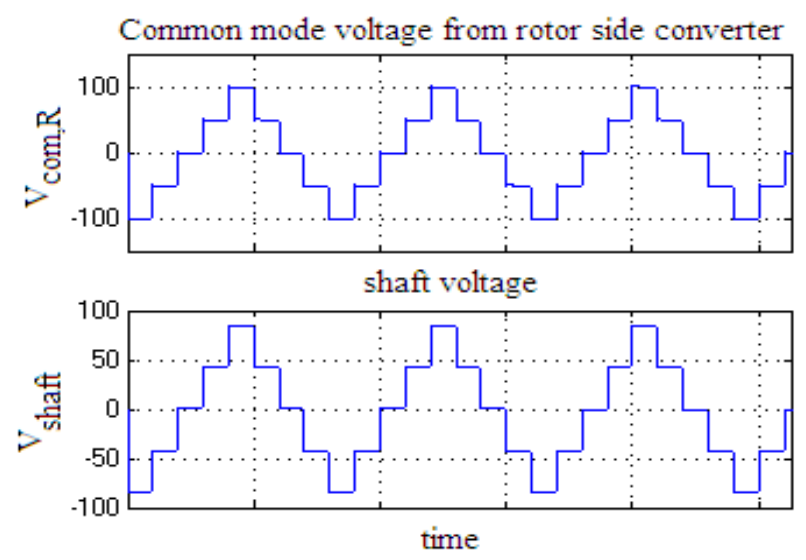

Fig.8. A typical rotor side common mode voltage waveform and its resultant shaft voltage

The capacitive coupling between the rotor winding and rotor frame has a significant value compared with other capacitances. Considering $\mathrm{C}_{\mathrm{wr}}>>\mathrm{C}_{\mathrm{b}}+\mathrm{C}_{\mathrm{rf}}+\mathrm{C}_{\mathrm{rs}}$, the major part of the common mode voltage will be placed across the shaft. Fig.8 shows a simulation result where the upper waveform is the common mode voltage from rotor side and lower one is resultant shaft voltage. It is clear that the majority of the rotor side common mode voltage transforms to shaft voltage.

Topopolgy2: A filter is placed in the rotor side converter and the voltage from the rotor side has fewer harmonic and no common mode voltage source. An arrangement of capacitive couplings in the proposed structure is shown in Fig.9. The only common mode voltage source is from the stator winding. By a KCL analysis for this configuration, and by considering $\mathrm{C}_{\mathrm{ws}} \& \mathrm{C}_{\mathrm{wf}}$ very small values in compare with other capacitances, the shaft voltage can be derived as:

$$
\left\{\begin{aligned}
\mathrm{V}_{\text {shaft }} & =\frac{\mathrm{C}_{\mathrm{sr}} \times\left(\mathrm{C}_{\mathrm{wr}}+\mathrm{C}_{\mathrm{wf}}+\mathrm{C}_{\mathrm{ws}}\right)+\mathrm{C}_{\mathrm{ws}} \times \mathrm{C}_{\mathrm{wr}}}{\left(\mathrm{C}_{\mathrm{wr}}+\mathrm{C}_{\mathrm{rf}}+\mathrm{C}_{\mathrm{b}}+\mathrm{C}_{\mathrm{sr}}\right) \times\left(\mathrm{C}_{\mathrm{ws}}+\mathrm{C}_{\mathrm{wr}}+\mathrm{C}_{\mathrm{wf}}\right)-\mathrm{C}_{\mathrm{wr}}^{2}} \times \mathrm{V}_{\mathrm{com}, \mathrm{S}} \\
& \approx \frac{\mathrm{C}_{\mathrm{sr}} \times \mathrm{C}_{\mathrm{wr}}}{\mathrm{C}_{\mathrm{wr}} \times\left(\mathrm{C}_{\mathrm{wr}}+\mathrm{C}_{\mathrm{rf}}+\mathrm{C}_{\mathrm{b}}+\mathrm{C}_{\mathrm{sr}}\right)-\mathrm{C}_{\mathrm{wr}}^{2}} \times \mathrm{V}_{\mathrm{com}, \mathrm{S}} \\
& =\frac{\mathrm{C}_{\mathrm{sr}} \times \mathrm{C}_{\mathrm{wr}}}{\mathrm{C}_{\mathrm{wr}}^{2}+\mathrm{C}_{\mathrm{wr}} \times\left(\mathrm{C}_{\mathrm{rf}}+\mathrm{C}_{\mathrm{b}}+\mathrm{C}_{\mathrm{sr}}\right)-\mathrm{C}_{\mathrm{wr}}^{2}} \times \mathrm{V}_{\mathrm{com}, \mathrm{S}}
\end{aligned}\right.
$$

Based on this calculation, shaft voltage is as follow:

$$
\mathrm{V}_{\text {shaft }}=\frac{\mathrm{C}_{\mathrm{sr}}}{\left(\mathrm{C}_{\mathrm{rf}}+\mathrm{C}_{\mathrm{b}}+\mathrm{C}_{\mathrm{sr}}\right)} \times \mathrm{V}_{\mathrm{com}, \mathrm{S}}
$$

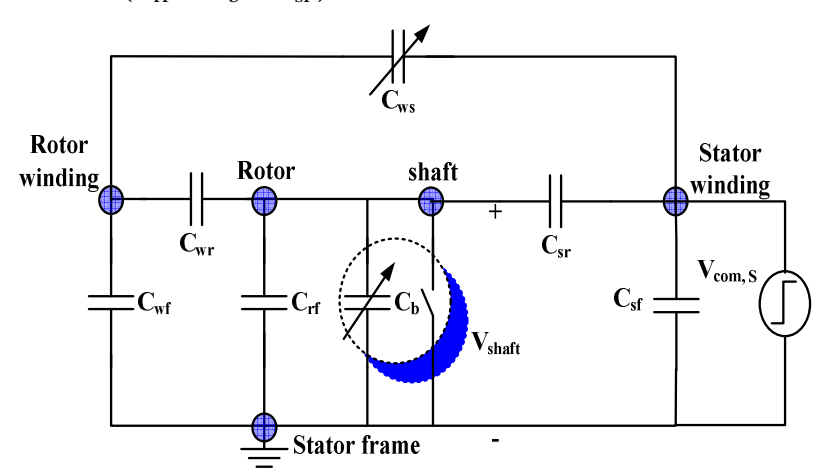

Fig.9. high frequency model of a DFIG with Topology2

Fig.10 shows a simulation result where the upper waveform is the common mode voltage from stator side and lower one is the resultant shaft voltage. In this case, $30 \%$ of the stator side common mode voltage converts to shaft voltage.
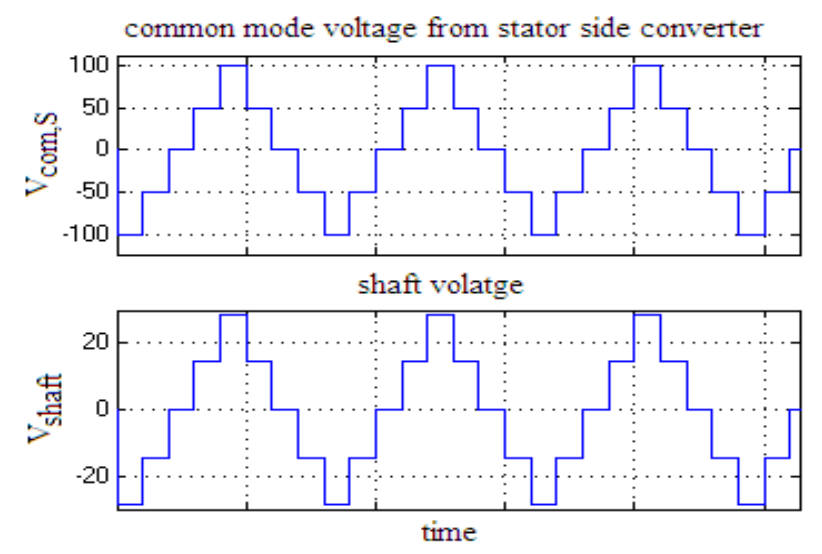

Fig.10. a typical stator side common mode voltage and its resultant shaft voltage

Topology3: Two LC filters in the both rotor and stator sides are used to damp the higher order harmonics. In this case, there is no any common mode voltage from both sides. Hence, the possibility of the shaft voltage generation has been reduced.

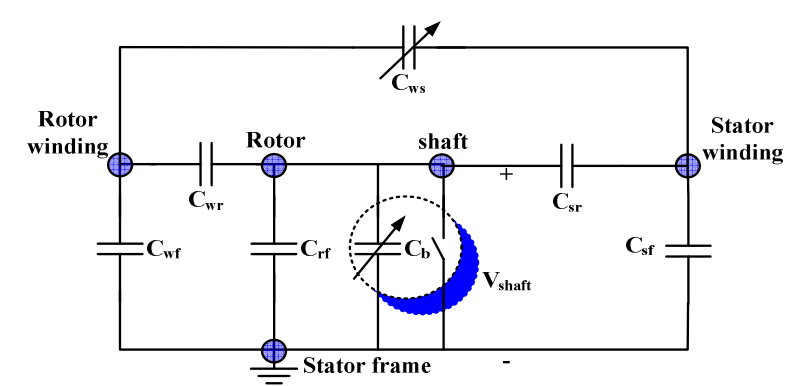

Fig.11. high frequency model of a DFIG with Topology3

Topology4: there is no LC filter in both converters sides. Fig.12 shows the high frequency model of a doubly fed induction machine without filters. In this structure, neutral to ground zero sequence voltage of both stator and rotor winding act as common mode voltage sources.

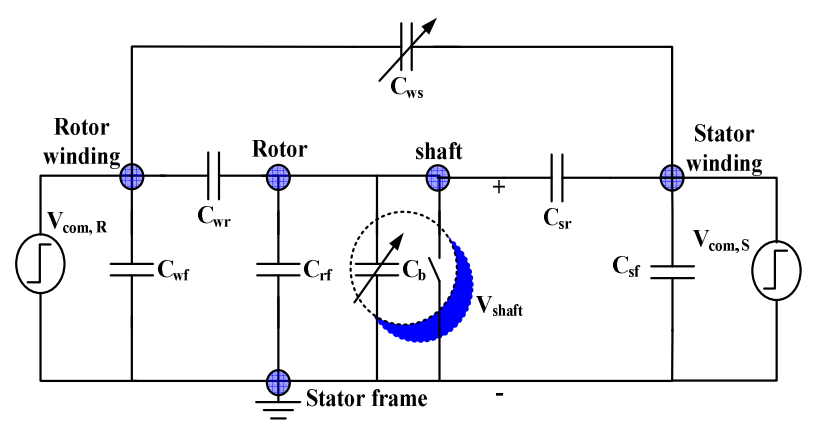

Fig.12. high frequency model of a DFIG with Topology4

The shaft voltage can be easily calculated by using KCL in the high frequency model of the doubly fed generator. According to Fig.12, the shaft voltage is:

$$
\begin{aligned}
V_{\text {shaft }} & =\frac{C_{w r}}{C_{w r}+C_{\text {rf }}+C_{b}+C_{\text {sr }}} \times V_{\text {com }, R}+\frac{C_{\text {sr }}}{C_{w r}+C_{r f}+C_{b}+C_{s r}} \times V_{\text {com } S} \\
& =K_{R} \times V_{\text {com }, R}+K_{S} \times V_{\text {coms }}
\end{aligned}
$$

$\mathrm{V}_{\text {com, } \mathrm{R}}$ and $\mathrm{V}_{\text {com,S }}$ are the common mode voltages from the rotor and stator windings, respectively. $\mathrm{KR}$ and $\mathrm{KS}$ are defined as capacitance factors which are effective in total shaft voltage generation. 
$\mathrm{K}_{\mathrm{R}}=\frac{\mathrm{C}_{\mathrm{wr}}}{\mathrm{C}_{\mathrm{wr}}+\mathrm{C}_{\mathrm{rf}}+\mathrm{C}_{\mathrm{b}}+\mathrm{C}_{\mathrm{sr}}}$ and $\mathrm{K}_{\mathrm{S}}=\frac{\mathrm{C}_{\mathrm{sr}}}{\mathrm{C}_{\mathrm{wr}}+\mathrm{C}_{\mathrm{rf}}+\mathrm{C}_{\mathrm{b}}+\mathrm{C}_{\mathrm{sr}}}$

Considering $\mathrm{C}_{\mathrm{wr}}>>\mathrm{C}_{\mathrm{rf}}+\mathrm{C}_{\mathrm{b}}+\mathrm{C}_{\mathrm{sr}}$, the shaft voltage is determined by $\mathrm{C}_{\mathrm{wr}}\left(\mathrm{K}_{\mathrm{R}}\right.$ is almost near 1 and $\mathrm{K}_{\mathrm{S}}$ is a small value).

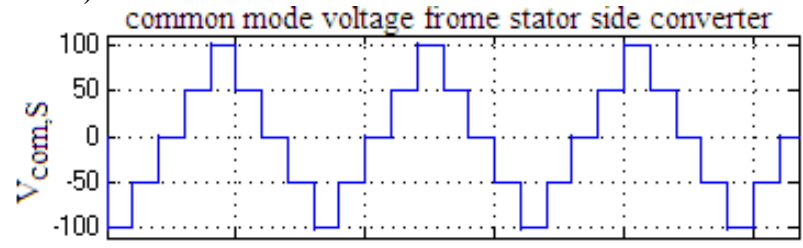

common mode voltage from rotor side converter
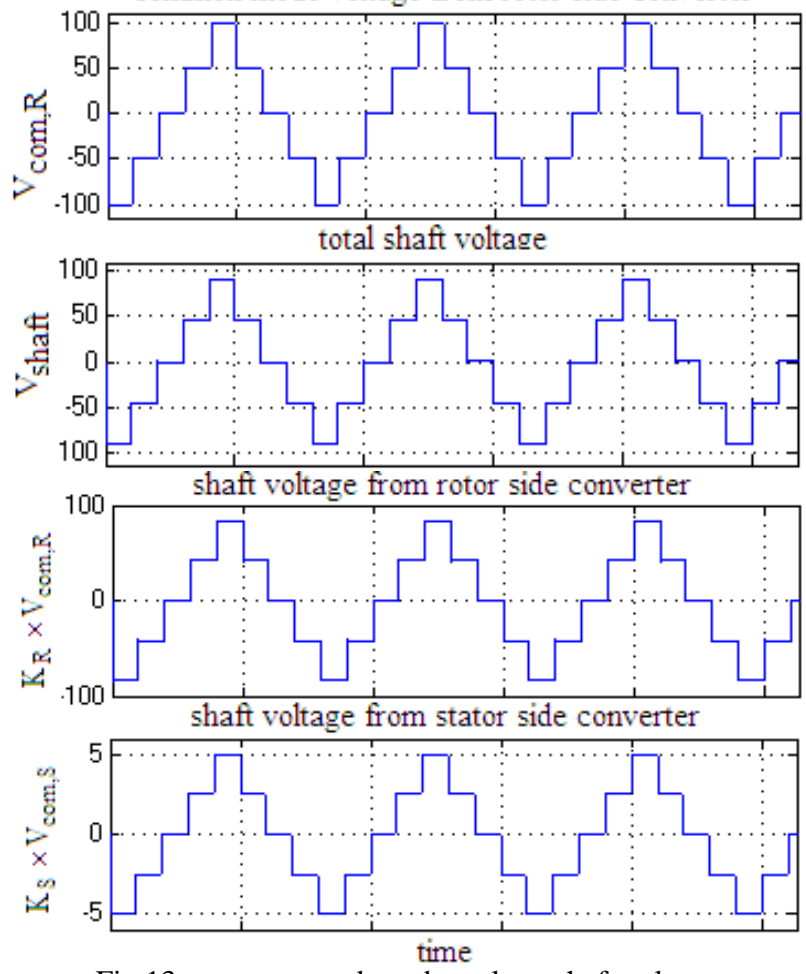

Fig.13. common mode and resultant shaft voltages

Fig.13 shows the simulation results for total shaft voltage and the share of each converter in shaft voltage generation. A major portion of the rotor side common mode voltage transformed to the shaft voltage (in this case, $83 \%$ of rotor side common mode voltage and only $5 \%$ of stator side common mode voltage). Based on this analysis, the stator common mode voltage does not have significant effect on the shaft voltage generation because the capacitive coupling between the stator winding and shaft is too small in comparison with the capacitance between the rotor winding and shaft.

\section{Discussion on different topologies and shaft voltage reduction techniques of DFIG}

In order to reduce the shaft voltage in a DFIG, it is important to consider the different LC filters locations to eliminate common mode voltage from each converter side. According to the above analysis, the common mode voltage from rotor side plays an effective role on shaft voltage generation. In this paper, possibilities to mitigate the shaft voltage of a DFIG have been introduced. Choosing one of these options depends on the cost of filtering, changing the PWM pattern and increasing switching frequency or employing additional circuits to reduce the rotor side voltage. Different topologies have been simulated in the previous part in case of shaft voltage generation. The effects of PWM techniques and filtering are investigated in each configuration.

The system configuration in Topology 1 can not remove the shaft voltage because the common mode voltage from the rotor still exists. This voltage has a major impact on the shaft voltage. In this case by removing stator side common mode voltage, a small part of shaft voltage will be removed (in Fig.8, only $5.86 \%$ of shaft voltage was eliminated.). Removing zero switching vectors in this case can reduce rotor side common mode voltage and as a result a reduced shaft voltage can be achieved. As mentioned in the previous section, removing the rotor side common mode voltage (Topology2) by filtering the rotor side converter will remove major part of the shaft voltage but there is a considerable amount of shaft voltage from the stator side. Removing zero switching vectors from stator side converter can reduce the common mode voltage and as a result a reduced shaft voltage can be achieved.

In these two topologies $(1 \& 2)$, the price for filtering is paid but there is still a considerable amount of shaft voltage. Furthermore, it is obvious that the configuration of Topology3, because of filtering in both sides, will remove both sides' common mode voltages and will not generate shaft voltage significantly.

In Topology4, to achieve a zero shaft voltage or at least reducing shaft voltage to an appropriate value, both common mode voltage sources should be considered based on an accurate high frequency model of the system. Using Eq.10 and Fig.12, it is clear that by choosing the rotor common mode voltage as follow, zero shaft voltage can be achieved.

$\mathrm{V}_{\mathrm{com}, \mathrm{R}}=-\frac{\mathrm{C}_{\mathrm{sr}}}{\mathrm{C}_{\mathrm{wr}}} \times \mathrm{V}_{\mathrm{com}, \mathrm{S}}$

Table II shows the resultant shaft voltage by different switching states generated by a back-to-back converter applied to the both rotor and stator sides. Note that, rotor side common mode voltage has been decreased to $\frac{\mathrm{C}_{\mathrm{sr}}}{\mathrm{C}_{\mathrm{wr}}} \times \mathrm{V}_{\mathrm{com}, \mathrm{S}}$ by a buck converter and shaft voltage is calculated based on Eq.10 and Table I.

Table II. Different switching states and shaft voltage

\begin{tabular}{|c|c|c|c|c|c|}
\hline & \multicolumn{4}{|c|}{ Rotor side converter } \\
\hline & & $\begin{array}{c}\text { Vectors } \\
1,3,5 \\
\end{array}$ & $\begin{array}{c}\text { Vectors } \\
2,4,6\end{array}$ & $\begin{array}{c}\text { Vector } \\
7 \\
\end{array}$ & $\begin{array}{c}\text { Vector } \\
0\end{array}$ \\
\hline \multirow{4}{*}{ 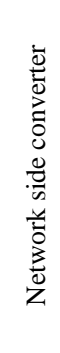 } & $\begin{array}{c}\text { Vectors } \\
1,3,5\end{array}$ & $\frac{-\mathrm{K}_{\mathrm{S}} \mathrm{V}_{\mathrm{dc}}}{3}$ & 0 & $\frac{\mathrm{K}_{\mathrm{S}} \mathrm{V}_{\mathrm{dc}}}{3}$ & $\frac{-2 \mathrm{~K}_{\mathrm{S}} \mathrm{V}_{\mathrm{dc}}}{3}$ \\
\hline & $\begin{array}{l}\text { Vectors } \\
2,4,6\end{array}$ & 0 & $\frac{\mathrm{K}_{\mathrm{S}} \mathrm{V}_{\mathrm{dc}}}{3}$ & $\frac{2 \mathrm{~K}_{\mathrm{S}} \mathrm{V}_{\mathrm{dc}}}{3}$ & $\frac{-\mathrm{K}_{\mathrm{S}} \mathrm{V}_{\mathrm{dc}}}{3}$ \\
\hline & $\begin{array}{l}\text { Vector } \\
7\end{array}$ & $\frac{\mathrm{K}_{\mathrm{S}} \mathrm{V}_{\mathrm{dc}}}{3}$ & $\frac{2 \mathrm{~K}_{\mathrm{S}} \mathrm{V}_{\mathrm{dc}}}{3}$ & $\mathrm{~K}_{\mathrm{S}} \mathrm{V}_{\mathrm{dc}}$ & 0 \\
\hline & $\begin{array}{l}\text { Vector } \\
0\end{array}$ & $\frac{-2 \mathrm{~K}_{\mathrm{S}} \mathrm{V}_{\mathrm{dc}}}{3}$ & $\frac{-\mathrm{K}_{\mathrm{S}} \mathrm{V}_{\mathrm{dc}}}{3}$ & 0 & $-\mathrm{K}_{\mathrm{S}} \mathrm{V}_{\mathrm{dc}}$ \\
\hline
\end{tabular}

To eliminate the shaft voltage, we need to generate shaft voltage on the rotor side based on Eq.13. To meet these requirements, it is needed to apply odd switching vectors $(1,3$, and 5$)$ to one converter and even switching vectors $(2,4$, and 6$)$ to another converter. Also, switching vector $\mathrm{V}_{0}$ from one side and vector $\mathrm{V}_{7}$ from other side is 
conducted to a zero shaft voltage. Fig.14 shows a typical common mode voltage from the rotor side, common mode voltage from stator side and resultant shaft voltage based on the proposed switching pattern. In this case, the rotor side voltage is decreased based on the ratio of $\mathrm{C}_{\mathrm{wr}}$ and $\mathrm{C}_{\mathrm{sr}}$ and the shaft voltage is forced to be zero.

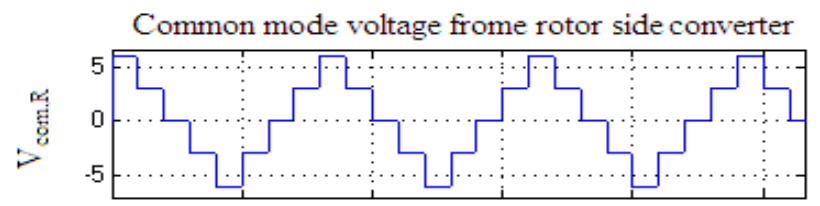

Common mode voltage frome stator side converter
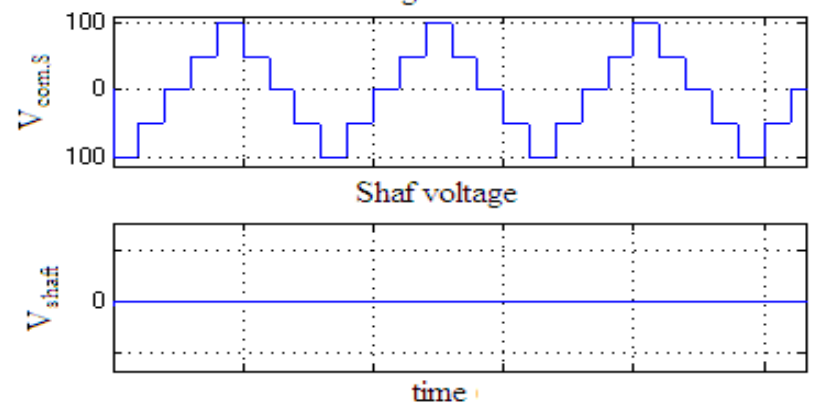

Fig.14. a typical common mode voltage and zero shaft voltage

From the analysis, it is obvious that the rotor side converter plays a key role in the shaft voltage generation of a DFIG structure. The presented PWM pattern can be used as an effective technique to reduce the shaft voltage. To achieve the conditions of Eq.13, a bidirectional buck converter has been used to decrease the rotor side common mode voltage.

\section{5. conclusions}

Different configurations of IG and DFIGs are analysed in terms of shaft voltage generation. Filtering in different converters side, PWM techniques and a circuit topology have been presented in order to reduce the shaft voltage. According to analyses, filtering in the rotor or stator side can not help to fully mitigate shaft voltage, and using PWM techniques can not eliminate the shaft voltage. A zero shaft voltage can be achieved by filtering at both sides converter because both sides' common mode voltage sources forced to be zero. The switching strategy presented in this paper is needed to apply odd switching vectors $(1,3$, and 5) to one converter and even switching vectors $(2,4$, and 6$)$ to another converter. Also, switching vector 0 from one side and vector 7 from the other side is conducted to a zero shaft voltage.

Regardless of different PWM strategies in different topologies, changing design parameters of a generators help to reduce the shaft voltage (see Fig.4) at the early design procedures. This technique is very effective in shaft voltage reduction of a stator fed IG. PWM techniques have some limitations in that structure to mitigate the common mode voltage and resultant shaft voltage (only removing zero switching states can help to reduce the shaft voltage). Therefore, one of the most important issues in shaft voltage generation of the induction generators is the mechanical structure of the machine which is directly proportional to capacitive couplings. Mathematical analysis and simulation results have been presented to verify the investigations.

\section{Acknowledgment}

The authors thank the Australian Research Council (ARC) for the financial support for this project through the ARC Discovery Grant DP0774497.

\section{References}

[1] S.Muller, M.Deicke, R.W.De Doncker, "Doubly fed induction generator systems for wind turbines", Industry Appl. Magazine, IEEE, vol. 8, pp. 26 -33, May. 2002.

[2] P.B. Eriksen, T. Ackermann, and etc. "System Operation with High Wind Penetration", IEEE Power \& Energy Magazine, pp.65-74, Nov 2005

[3] Yi Zhang, S.Ula, "Comparison and evaluation of three main types of wind turbines", Transmission and Distribution Conference and Exposition, IEEE/PES, pp.1-6, April 2008

[4] H.o.Rostoen, T.M. Undeland ,T.Gjengedal, "Doubly Fed Induction Generator in a Wind Turbine" 3rd International Workshop on Hydro Scheduling in Competitive Electricity Market ,Oslo, . June 2008

[5] S. K Salman and Babak Badrzadeh, "New Approach for modelling Doubly-Fed Induction Generator (DFIG) for grid-connection studies" European wind energy conference an exhibition, London, Nov.2004

[6] J. M. Erdman, R. J. Kerkman, D. W. Schlegel, "Effect of PWM inverters on AC motor bearing currents and shaft voltages," Industry Applications, IEEE Transactions on, vol. 32, pp. 250-259, 1996.

[7] C. Mei, J. C. Balda, W. P. Waite, and K. Carr, "Minimization and cancellation of common-mode currents, shaft voltages and bearing currents for induction motor drives," presented at Power Electronics Specialist Conference, 2003. PESC '03, IEEE 34th Annual, 2003.

[8] M. M. Swamy, K. Yamada, and T. Kume, "Common mode current attenuation techniques for use with PWM drives," Power Electronics, IEEE Transactions on, vol. 16, pp. 248-255, 2001.

[9] J.Adabi, F.Zare, G.Ledwich, A.Ghosh, "Leakage Current and Common Mode Voltage Issues in Modern AC Drive Systems", AUPEC, Perth, Australia, Dec 2007.

[10] J.Zitzelsberger, W.Hofmann, A.Wiese, "Bearing Currents in Doubly-Fed Induction Generators", Power Electronics and Applications, 2005 European Conference on, 11-14 Sept. 2005

[11] A.M.Garcia, D.G. Holmes, T.A. Lipo, ," Reduction of Bearing Currents in Doubly Fed Induction Generators" Industry Applications Conference, 2006. 41st IAS Annual Meeting, Conference Record of the 2006 IEEE, Volume 1, pp. 84-89 